\title{
PENGEMBANGAN BUKU PENGAYAAN MENULIS TEKS ANEKDOT BERMUATAN CINTA TANAH AIR
}

\author{
Rahman Saleh Alfarisi ${ }^{1}$, Suseno ${ }^{2}$ \\ rahmansalehalfarisi@gmail.com
}

\author{
Prodi Pendidikan Bahasa dan Sastra Indonesia, Fakultas Bahasa dan Sastra Indonesia \\ Universitas Negeri Semarang, Indonesia
}

\begin{abstract}
Abstrak
Tujuan penelitian ini 1) memaparkan kebutuhan guru dan siswa terhadap buku pengayaan menulis teks anekdot bermuatan cinta tanah air, 2) memaparkan prinsip pengembangan buku pengayaan menulis teks anekdot bermuatan cinta tanah air, 3) mendeskripsikan prototipe pengembangan buku pengayaan menulis teks anekdot bermuatan cinta tanah air, dan 4) memaparkan hasil penilaian dan perbaikan prototipe buku pengayaan menulis teks anekdot bermuatan cinta tanah air. Penelitian ini menggunakan metode research and devolopment yang dilakukan dengan lima tahapan: 1) potensi dan masalah, 2) pengumpulan data, 3) desain produk, 4) validasi produk, dan 5) revisi desain. Hasil dari penelitian ini, Pertama, hasil analisis kebutuhan siswa dan guru terhadap pengembangan buku pengayaan menulis teks anekdot bermuatan cinta tanah air yang menghasilkan prinsip-prinsip pengembangan buku pengayaan. Guru dan siswa berharap buku pengayaan yang sesuai dengan tingkatan siswa, disusun dengan bahasa yang mudah dimengerti dan diberi materi yang lengkap serta contohcontoh teks anekdot yang menumbuhkan nilai cinta tanah air. Kedua, prinsip-prinsip pengembangan buku pengayaan menulis teks anekdot bermuatan cinta tanah air ditetapkan menjadi 5 aspek pengembangan buku, antara lain: 1) aspek materi, 2) aspek penyajian materi, 3) aspek bahasa, 4) aspek grafika dan 5) aspek muatan cinta tanah air. Ketiga, prototipe buku pengayaan menulis teks anekdot bermuatan cinta tanah air. Buku pengayaan ini terdiri dari, kulit buku, bagian awal, bagian isi, dan bagian akhir. Keempat, hasil penilaian yang dilakukan dosen ahli semua aspeknya tergolong baik. Perbaikan berdasarkan penilaian dan saran perbaikan dosen ahli, peneliti melakukan 15 perbaikan pada buku pengayaan menulis teks anekdot bermuatan cinta tanah air.
\end{abstract}

Kata kunci : buku pengayaan, cinta tanah air, menulis teks anekdot.

\begin{abstract}
The purpose of this study are 1) to explain the necessity of teachers and students for enrichment books in writing anecdotal texts containing love of the motherland, 2) to describe the principles in developing the enrichment books to write anecdotal texts containing love of the motherland, 3) to describe the prototypes of the development of enrichment books in writing anecdotal texts containing love of the motherland, and 4) to explain the results of the assessment and improvement of the prototype of the enrichment books in writing anecdotal texts containing the love of the motherland. This research uses research and development methods which are carried out in five stages: 1) potential and problems, 2) data collection, 3) product design, 4) product validation, and 5) design revision. The results of this study as follows, First, the analysis of the necessity of students and teachers on the development of the enrichment books in writing anecdotal texts containing the love of the motherland which results in the principles of enrichment book development. Teachers and students expect enrichment books that are suitable for the students level to be easily understood and given complete material and examples of anecdotal texts that foster the value of patriotism. Second, the principles of developing an enrichment book to write anecdotal texts containing love for the motherland are set into 5 aspects of book development, including: 1) material aspects, 2) material presentation aspects, 3) language aspects, 4) graphic aspects and 5) love of the motherland aspects. Third, the prototype of the enrichment books to write anecdotal texts containing love of the motherland. The enrichment book consists of the book cover, beginning section, content section, and appendix. Fourth, the results of the assessment conducted by expert lecturers were considered good in all aspects. The Improvements are based on the assessment and suggestions from expert lecturers, researchers made 15 improvements with the enrichment book in writing anecdotal texts containing the love of the motherland.
\end{abstract}

Keywords: enrichment books, love of the motherland, writing anecdotal texts.

\section{PENDAHULUAN}

Buku adalah peninggalan yang masih relevan di sepanjang zaman (Kompasiana, 2017). Meskipun buku mengalami pembaruan secara terus menerus tetapi pembaca tidak lantas membuang bukubuku yang lama. Buku lama dijadikan acuan sebagai pembanding buku baru. Pembandingan yang dilakukan akan memunculkan pemikiran yang kritis.
Pembelajaran yang dilakukan peserta didik menggunakan buku sebagai sumber belajar yang pokok. Hal ini sesuai dengan pernyataan dari Muchlis (dalam Pertiwi, Hartono, \& Syaifudin, 2016: 63) bahwa buku merupakan bagian dari kelangsungan pendidikan. Adanya buku proses pembelajaran dapat berjalan dengan lancar sehingga buku menjadi bagian penting dalam proses pembelajaran.

102 | Jurnal Kredo

Vol. 3 No. 1 Oktober 2019 
Pembelajaran bahasa Indonesia dalam kurikulum 2013 menerapkan pembelajaran berbasis teks. Pembelajaran yang menuntut peserta didik untuk memahami berbagai jenis teks dan mahir untuk menulis teks. Teks merupakan ungkapan pikiran manusia yang lengkap yang di dalamnya memiliki situasi dan konteks dapat berwujud tulis maupun lisan. Teks tulis atau lisan mampu mengasah keterampilan berbahasa peserta didik. Hal tersebut sesuai dengan esensi keterampilan menulis yang mengarah pada kegiatan mengekspresikan gagasan, ide, pendapat atau pikiran dan perasaan dalam bentuk tulisan (Zulaeha, 2016: 11). Lebih dari itu, menulis merupakan kegiatan mengerahkan ide, gagasan, pikiran atau perasaan untuk merangkai kata-kata yang dikuasainya menjadi sebuah tulisan yang bermakna (Zulaeha 2017: 482). Selain itu, dari keempat keterampilan berbahasa menulis merupakan keterampilan tertinggi yang dimiliki oleh seseorang (Rosidi, 2009: 2).

Teks yang dibelajarkan dalam pembelajaran bahasa Indonesia SMA kelas $\mathrm{X}$ yaitu teks menggambarkan atau describing, menjelaskan atau explaining, memerintah atau instructing, argumen atau arguing, menceritakan atau narrating.

Ruang lingkup materi bahasa Indonesia untuk SMA/MA/SMK/MAK kategori umum kelas $\mathrm{X}$, antara lain: laporan hasil observasi, teks eksposisi, anekdot, hikayat, ikhtisar buku, teks negosiasi, debat, cerita ulang (biografi), puisi dan resensi buku (Kemendikbud, 2016).

Salah satu teks yang dipelajari pada peserta didik SMA/MA/SMK/MAK pada kurikulum 2013 adalah teks anekdot. Teks anekdot dalam pembelajaran bahasa Indonesia di kelas $\mathrm{X}$ bertujuan untuk melatih siswa berpikir kritis dan kreatif dalam menyelesaikan permasalahan dalam kehidupan nyata dengan cara yang unik dan lebih baik. Penelitian tentang pembelajaran menulis teks anekdot dianggap penting untuk diteliti mengingat bahwa teks anekdot merupakan materi yang baru dan belum pernah diajarkan sebelumnya (Rahmayanti, Martha, \& Wisudariani, 2015: 4).

Kemunculan teks anekdot dalam kurikulum 2013 mata pelajaran bahasa Indonesia yang terbilang baru. Ada tiga kendala yang dialami siswa dalam menulis teks anekdot yaitu, 1) siswa mengalami kesulitan dalam menentukan cerita yang tergolong lucu. Hal ini disebabkan oleh kadar/tingkat kelucuan yang dimiliki oleh setiap orang siswa berbeda-beda. Boleh jadi apa yang menurut mereka lucu menurut orang lain itu tidak lucu. 2) siswa merasa kesulitan dalam menyusun dialog, utamanya dialog-dialog yang menandai unsur-unsur teks anekdot seperti abstraksi, orientasi, krisis, reaksi, dan koda. Dengan kata lain, siswa merasa kesulitan ketika menyusun dialog dengan mengaplikasikan struktur teks anekdot. 3) siswa merasa kesulitan dalam menyatu-padukan unsur lucu bernuansa sindiran. Dengan kata lain siswa kesulitan dalam menyusun cerita yang bersifat lucu, tetapi sebenarnya unsur lucu tersebut dimaksud untuk menyindir seseorang (Rahmayanti, Martha, \& Wisudariani, 2015: 10).

Berdasarkan dengan observasi lapangan serta wawancara dengan tiga guru bahasa Indonesia dari sekolah dengan latar belakang yang berbeda supaya data yang dihasilkan mempresentasikan kondisi mayoritas siswa dan guru. Ketiga sekolah yang dipilih adalah SMA Negeri 1 Ambarawa, SMA Sudirman, dan SMA Baktiawam yang berada di daerah Ambarawa. Berdasarkan observasi dan wawancara tersebut, diterapkannya kurikulum 2013 menyebabkan guru kesulitan dalam penyesuaian, baik dalam kesiapan mengajar maupun dalam kesiapan bahan ajar. Hal itu disebabkan oleh terbatasnya materi baru dan media yang mendukung, terutama pada materi teks anekdot. Jenis teks yang baru menyebabkan guru kesulitan dalam mencari media cocok 
dengan materi dan tingkatan kelas siswa. Hal ini menyebabkan pengaruh terhadap hasil tulisan siswa yang kurang memuaskan. Padahal kemampuan menulis teks anekdot dapat dimanfaatkan peserta didik untuk mendokumentasikan konflik maupun fenomena sosial yang dijumpainya disekitar lingkungan.

Salah satu sarana prasarana yang dapat menunjang pembelajaran ialah bahan ajar. Hal ini diperkuat dengan penelitian yang dilakukan oleh Pertiwi, Hartono, \& Syaifudin (2016: 63) yang menemukan bahwa pergantian kurikulum yang memunculkan beberapa teks baru, belum diiringi oleh kesiapan buku penunjang. Bahan ajar sendiri terdiri atas berbagai jenis, salah satunya ialah buku. Ada dua macam buku yaitu buku teks dan buku nonteks. Buku tersebut sangatlah penting dalam berlangsung pembelajaran.

Kurang tersedianya buku untuk menunjang proses pembelajaran menjadi kendala dalam pelaksanaan pembelajaran. Hal ini sesuai dengan pernyataan Supriyoko (dalam Pertiwi, Hartono, \& Syaifudin, 2016: 63), menyatakan bahwa minimnya buku penunjang lainnya menjadi salah satu kendala dalam pembelajaran. Minimnya buku menjadikan proses pembelajaran akan terhambat. Hal ini akan membuat peserta didik dan guru memiliki referensi buku yang kurang. Hal itu menyebabkan tidak luasnya wawasan dari siswa dan guru.

Adanya kendala tersebut, buku pengayaan menjadi salah satu solusi untuk mengatasi minimnya buku pengunjung untuk peserta didik maupun guru. Hal ini sesuai dengan Peraturan Menteri Pendidikan Nasional (Permendiknas) RI Nomor 2 Tahun 2008 Tentang Buku Pasal 6 Ayat 2 yang menyatakan bahwa selain buku teks, guru dapat menggunakan buku panduan pendidik, buku pengayaan, dan buku referensi dalam proses pembelajaran. Selain itu, Sitepu (2014: 17) menyatakan bahwa buku pengayaan adalah buku yang memuat materi yang dapat memperkaya buku teks pendidikan dasar, menengah dan perguruan tinggi. Berdasarkan pernyataan tersebut, buku pengayaan menjadi hal penting untuk meningkatkan kemampuan siswa dalam proses pembelajaran.

Buku pengayaan memiliki kelebihan yaitu cakupan materi lebih luas, sehingga membuat pembaca menjadi lebih memahami dengan rinci topik atau judul yang sedang dibahas. Selain itu, buku pengayaan juga tidak memiliki masa edar yang singkat, sehingga penggunanya bisa digunakan dalam jangka waktu panjang. Buku pengayaan memiliki fokus pembahasan topik atau judul sehingga pembaca tidak mengalami kebingungan. Hal ini sesuai dengan pernyataan Wahyudi (2010) menyatakan bahwa beberapa kelebihan dari buku pengayaan antara lain mempunyai cakupan materi yang lebih luas, masa edar yang lebih lama, kajian hanya fokus ke topik/judul sehingga tidak melelahkan dan dapat ditulis tanpa batas waktu. Berdasarkan dari pernyataan tersebut maka buku pengayaan yang dikembangkan pada penelitian ini, fokus pada satu keterampilan menulis teks anekdot. Buku pengayaan yang fokus pada satu keterampilan berbahasa lebih mudah diterima siswa.

Buku pengayaan teks anekdot diintegrasikan dengan cinta tanah air dalam rangka membangun kepribadian siswa semakin bangga dengan tanah airnya. Cinta tanah air merupakan pedoman dalam hidup berbangsa dan bernegara untuk saling menjaga rasa damai dan aman terhindar dari kericuhan, mengharumkan nama bangsa dengan cara berprestasi, dan menjaga nama baik negara. Sebaliknya, tanpa cinta tanah air suatu negara akan banyak mengalami pemberontakan dan kericuhan. Cinta tanah air harus ditanamkan sejak usia dini baik di lingkungan keluarga, bermain, maupun sekolah. Penanaman nilai cinta tanah air sangat erat kaitannya dalam pembentukan karakter siswa yang 
berguna bagi pembangunan bangsa. Oleh karena itu sangat penting bagi sekolah, terutama guru, untuk menanamkan nilai cinta tanah air ke dalam diri siswa, sehingga siswa memiliki karakter cinta tanah air sebagai bekal sebagai generasi penerus bangsa (Widayani.N.E., 2016: 315)

Berdasar hasil wawancara dengan guru pengampu mata pelajaran bahasa Indonesia pada tiga sekolah yang dipilih adalah SMA Negeri 1 Ambarawa, SMA Sudirman, dan SMK Baktiawam SMA siswa memiliki karakter cinta tanah air masih kurang. Hal tersebut terbukti ketika siswa upacara bendera bermain hp atau bercanda dengan temannya, dalam berkomunikasi lebih suka menggunakan bahasa asing daripada bahasa Indonesia, dan lain-lain.

Cinta tanah air dan bangsa merupakan salah satu perwujudan dari nilai patriotisme yang harus tumbuh dan berkembang dalam jiwa generasi muda bangsa indonesia (Rianto, Firmansyah, 2017: 87). Sikap patriotisme yang dimiliki setiap penduduk suatu negara akan menghasilkan lancarnya pembangunan bangsa dan keharmonisan pada setiap penduduknya. Seseorang yang memiliki sikap patriotisme pasti tidak akan mengenal menyerah dan selalu sebagai pembaruan serta memiliki rasa tolong menolong yang tinggi. Penghayatan nilainilai patriotisme akan mampu mendorong individu untuk bertakwa kepada Tuhan Yang Maha Esa, suka bekerja keras dengan sepenuh hati, rela berkorban, bertanggung jawab, menjunjung tinggi nilai-nilai kemanusiaan serta mencintai bangsa dan negara (Rianto, Firmansyah, 2017: 87).

Berdasarkan hal tersebut peneliti melakukan penelitian mengenai pengembangan buku pengayaan menulis teks anekdot bermuatan cinta tanah air untuk menumbuhkan sikap patriotisme untuk siswa Sekolah Menengah Atas (SMA).

\section{KAJIAN TEORI}

Buku pengayaan merupakan buku yang dapat memerkaya peserta didik dalam bidang pengetahuan, keterampilan, dan kepribadian (Suryaman, 2010: 2). Jenis buku pengayaan meliputi buku pengayaan pengetahuan, keterampilan, dan kepribadian. Penyusunan buku berdasarkan kurikulum yang berlaku. Buku pengayaan hanya digunakan peserta didik sebagai pelengkap dalam pembelajaran. Buku pengayaan adalah buku yang memuat materi yang dapat memperkaya buku teks pendidikan dasar, menengah, dan perguruan tinggi (Sitepu, 2014: 17). Materi yang terdapat pada buku pengayaan merupakan bagian dari kurikulum yang berlaku. Buku pengayaan hanya digunakan sebagai referensi lain dari buku teks yang digunakan peserta didik. Buku pengayaan hanya melengkapi buku teks yang digunakan peserta didik. Buku pengayaan adalah buku yang berisi jabaran materi pembelajaran yang digunakan untuk pengayaan belajar anak (Hartono, 2016: 12). Kegunaan buku pengayaan untuk menambah keluasan dan kedalaman materi pembelajaran. Buku pengayaan berfungsi sebagai pelengkap buku teks saja tidak menjadi acuan wajib dalam proses belajar dan pembelajaran bagi peserta didik dan guru, tetapi berguna bagi peserta didik yang mengalami kesulitan memahami pokok bahasan tertentu dalam buku pelajaran pokok. Penyusunan buku ini berdasarkan kurikulum yang berlaku. Berdasarkan pendapat tersebut dapat disimpulkan bahwa buku pengayaan adalah buku yang memuat materi yang mengacu pada kurikulum yang berlaku.

Ciri-ciri buku nonteks tersebut menurut Pusat Perbukuan Departemen Pendidikan Nasional (2008: 2) sebagai berikut.

1) Buku-buku yang bukan merupakan buku acuan wajib bagi peserta didik meski dapat digunakan pada sekolah ataupun lembaga pendidikan, 
2) Materi yang disajikan dalam buku bersifat memperkaya pembaca mengenai informasi secara lebih luas,

3) Buku tidak diterbitkan secara berseri menurut tingkatan kelas atau jenjang pendidikan,

4) Materi dalam buku nonteks tidak terkait secara langsung dengan standar kompetensi ataupun kompetensi dasar dalam standar isi, akan tetapi menunjang pencapaian tujuan pembelajaran,

5) Isi dari buku nonteks dapat dimanfaatkan oleh semua jenjang pembaca, dan

6) Penyajian buku nonteks tidak terikat pada sistematika tertentu, melainkan bersifat longgar, kreatif, dan inovatif.

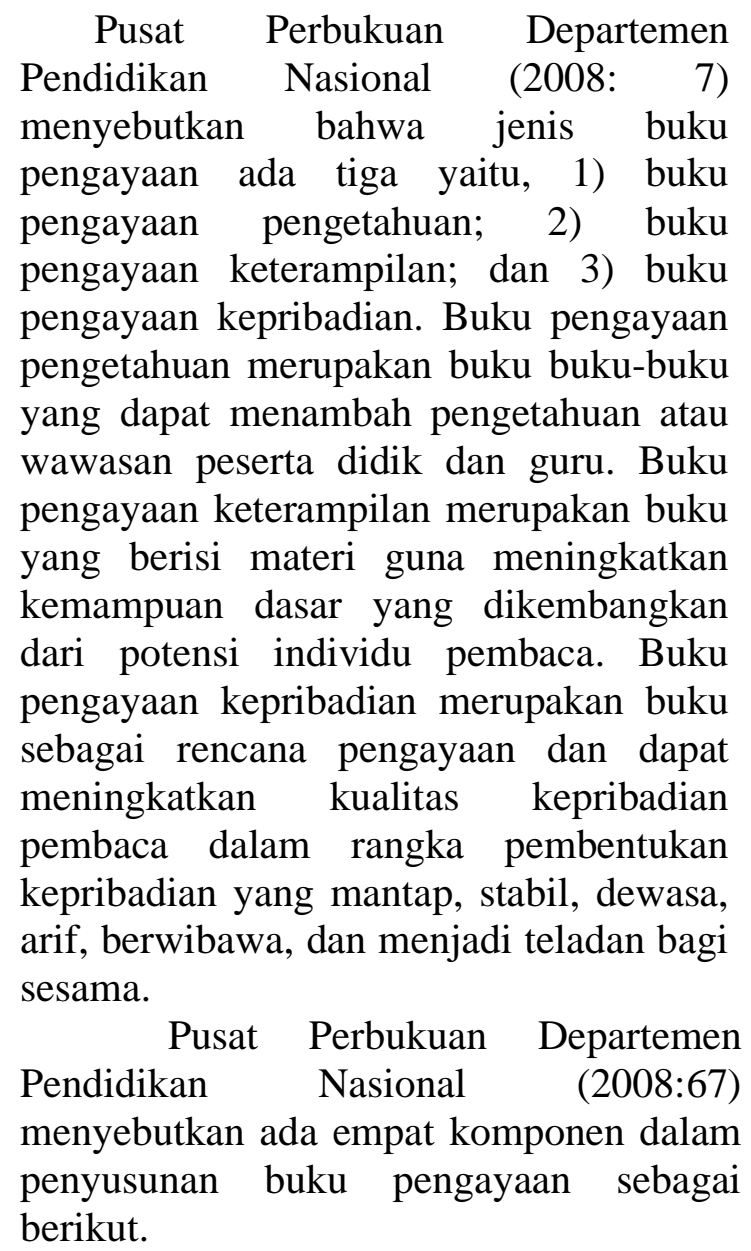

\section{a) Komponen Materi atau Isi Buku}

Terdapat komponen umum serta komponen khusus dalam mengembangkan buku pengayaan keterampilan. Adapun komponen umum terdiri atas 1) materi mendukung pencapaian tujuan pendidikan nasional, 2) materi tidak bertentangan dengan ideologi serta politik negara, 3) materi menghindari SARA, bias gender, serta pelanggaran HAM. Komponen khusus buku ini ialah kemutakhiran materi serta keakuratan materi. Materi atau isi dari buku pengayaan keterampilan hendaknya mampu mengembangkan kecakapan akademik, sosial, dan kejuruan (vocasional) untuk memecahkan masalah dan mendorong "jiwa kewirausahaan". Berdasarkan uraian tersebut, dapat disimpulkan komponen materi pada buku pengayaan teks eksposisi bermuatan antikorupsi yang akan dikembangkan memiliki kriteria sebagai berikut. Pertama, materi mendukung pencapaian tujuan pembelajaran nasional. Kedua, materi tidak bertentangan dengan ideologi serta politik negara. Ketiga, materi tidak mengandung unsur SARA, bias gender, maupun pelanggaran HAM. Keempat, menyajikan materi yang mampu mengembangkan kecakapan akademi, sosial serta pemecahan masalah.

\section{b) Komponen Penyajian}

Materi harus disajikan secara runtut, bersistem, lugas, dan mudah dipahami dalam penuyusunan buku nonteks pelajaran (Pusbuk, 2008: 74). Untuk buku pengayaan keterampilan, selain penyajian materi dilakukan secara runtut, bersistem, lugas, dan mudah dipahami, juga harus memerhatikan: 1) materi yang disajikan mudah dipahami, familiar, dan menyenangkan; 2) penyajian materi dapat memicu pengembangan kretivitas, aktivitas fisik/psikis, dan memicu pembaca untuk menerapkan (Pusbuk, 2008: 75).

Keruntutan dapat dilakukan dengan cara mengurutkan materi dari yang sederhana atau mudah terlebih dahulu, kemudian bertahap ke materi yang lebih kompleks atau sulit. Atau dapat pula dilakukan dengan menyajikan hal yang umum terlebih dahulu kemudian menyajikan hal-hal yang bersifat khusus, dapat pula dilakukan sebaliknya. Adapun standar perancangan penyajian 
bahan ajar meliputi beberapa kriteria, yakni pencantuman tujuan pembelajaran, penahapan pembelajaran, penarikan minat dan perhatian siswa, kemudahan pemahaman, pelibatan keaktifan siswa, hubungan antarbahan, dan penyertaan soal dan latihan.

\section{c) Komponen Bahasa atau Keterbacaan}

Penggunaan bahasa harus diperhatikan dalam penulisan buku pengayaan. Bahasa digunakan sebagai sarana untuk menyampaikan pikiran, gagasan, dan perasaan terhadap orang lain menggunakan simbol-simbol (Sitepu, 2012: 109). Agar pikiran, gagasan, dan perasaan dapat tersampaikan dengan baik, bahasa yang digunakan harus tepat, jelas, dan lugas. Hal ini sejalan dengan Pusbuk (2008: 78) menjelaskan bahwa ada beberapa hal yang harus diperhatikan oleh penulis buku nonteks mengenai komponen bahasa atau ilustrasi. Beberapa hal yang harus diperhatikan tersebut antara lain: 1) buku yang menggunakan ilustrasi, ilustrasinya harus proporsional; 2) buku yang menggunakan istilah atau simbol harus berlaku secara menyeluruh; 3) dalam penggunaan bahasa yang meliputi ejaan, kata, kalimat, dan paragraf harus tepat, lugas, dan jelas.

Buku yang baik harus memiliki tingkat keterbacaan yang tinggi, untuk itu penulis harus menyesuaikan penggunaan bahasa dengan sasaran buku tersebut. Buku nonteks yang baik mengandung kriteria bahasa meliputi 1) komunikatif, 2) dialogis dan interaktif, 3) lugas, 4) memiliki keruntutan alur pikir, 5) memiliki koherensi, 6) memiliki kesesuaian dengan kaidah bahasa Indonesia yang benar, serta 7) memiliki kesesuaian istilah, simbol, dan lambang dengan perkembangan peserta didik.

\section{d) Komponen Grafika}

Menurut Muslich (2010: 306) terdapat tiga indikator yang harus diperhatikan terkait komponen grafika pada bahan ajar. Ketiga indikator tersebut yaitu ukuran buku, desain kulit buku, dan desain isi buku. Desain kulit buku hendaknya mencerminkan isi buku. Adapun desain ini buku harus memerhatikan tata letak yang konsisten, harmonis, dan lengkap serta menggunakan tipografi yang sederhana, mudah dibaca dan dipahami.

Berdasarkan uraian tersebut, dapat disimpulkan bahwa buku pengayaan menyusun teks eksposisi bermuatan antikorupsi memiliki karakteristik yang berbeda dengan buku pengayaan keterampilan pada umumnya. Buku pengayaan menyusun teks eksposisi memiliki karakteristik sebagai berikut: 1) sebagai buku pengayaan keterampilan, buku tersebut dapat meningkatkan kualitas pengetahuan pembaca, 2) buku tersebut dapat digunakan di sekolah atau lembaga pendidikan, tetapi bukan merupakan buku acuan wajib bagi peserta didik dalam mengikuti kegiatan pembelajaran; dan 3) buku tersebut memiliki peran dalam menumbuhkan kesadaran antikorupsi pada peserta didik.

Menulis adalah mencoretkan huruf atau angka dengan pena dan sebagainya di atas kertas atau yang lain (Kamus Terbaru Bahasa Indonesia). Tarigan (1986: 21), mengemukakan bahwa menulis adalah menurunkan atau melukiskan lambanglambang grafik yang menggambarkan suatu bahasa yang dipahami oleh seseorang, sehingga orang lain dapat membaca lambang-lambang grafik tersebut sepanjang mereka memahami bahasa dan gambaran grafik tersebut. Menulis merupakan keterampilan berbahasa yang digunakan untuk berkomunikasi secara tidak langsung, tidak secara tatap muka dengan orang lain. Menulis merupakan suatu kegiatan produktif yang ekspresif.

Wiyanto (2006: 1) memberikan dua definisi menulis, yaitu pertama, menulis berarti mengubah bunyi yang dapat didengar menjadi tanda-tanda yang dapat dilihat. Bunyi yang dapat diubah itu disebut bunyi bahasa, yaitu bunyi yang dihasilkan oleh alat ucap manusia. Kedua, menulis mempunyai arti kegiatan mengungkapkan gagasan tertulis. Hakikat 
menulis merupakan salah satu keterampilan berbahasa yang merupakan kegiatan perekaman bahasa lisan ke dalam bahasa tulis. Untuk menghasilkan suatu tulisan yang baik, penulis diharuskan memiliki keterampilan dasar dalam menulis, sebagai berikut:

1) Keterampilan berbahasa, mencakup: keterampilan menggunakan ejaan dan tanda baca, pembentukan kata, pemilihan kata dan penggunaan kalimat yang efektif.

2) Keterampilan penyajian, keterampilan pembentukan dan pengembangan paragraf, keterampilan merinci pokok bahasan dan menyusun pokok bahasan serta sub pokok bahasan ke dalam susunan yang sistematis. Keterampilan ini memungkinkan tulisan dapat diikuti pembaca dengan mudah.

3) Keterampilan perwajahan, keterampilan pengaturan tipografi dan pemanfaatan sarana tulis secara efektif dan efisien, seperti: format penyusunan, pemilihan ukuran kertas, tipe huruf, penjilidan, penyusunan tabel, dan lain-lain sehingga dapat mendukung kesempurnaan serta kerapian.

Menulis merupakan keterampilan berbahasa aktif. Menulis merupakan kemampuan puncak seseorang untuk dikatakan terampil berbahasa. Menulis merupakan keterampilan yang sangat kompleks. Menulis tulisan juga merupakan media untuk melestarikan dan menyebarluaskan ilmu pengetahuan (Nurjamal dan Sumirat, 2010: 4).

Kementrian Pendidikan dan Kebudayaan Menerbitkan buku dengan judul "Bahasa Indonesia Ekspresi Diri dan Akademik" salah satunya adalah pengertian teks anekdot. Anekdot ialah cerita singkat yang menarik karena lucu dan mengesankan, biasanya mengenai orang penting atau terkenal dan berdasarkan kejadian yang sebenarnya.Hal-hal yang aneh dan nyeleneh dapat dijadikan humor (Setiawan, 1990), sehingga tidak menutup kemungkinan bahwa segala sesuatu yang ada di dunia ini berpotensi untuk dijadikan bahan lelucon. Pendapat selanjutnya mengenai teks anekdot, Keraf (2007: 142) mendefinisikan anekdot merupakan semacam cerita pendek yang bertujuan menyampaikan karakteristik yang menarik dan aneh mengenai seseorang atau suatu hal lain. Anekdot yang menjadi bagian dari narasi yang lebih luas, sama sekali tidak menunjang gerak umum dari narasi tadi, namun perhatian sentral yang dibuatnya dapat menambah daya tarik bagi latar belakang dan suasana secara keseluruhan. Daya tariknya itu tidak terletak pada penggelaran dramatik, tetapi pada suatu gagasan atau suatu amanat yang ingin disingkapkannya, dan biasanya muncul menjelang akhir kisah.

Terdapat lima unsur dalam teks anekdot (Kemendikbud, 2013: 113). Lima bagian tersebut, antara lain: abstrak, orientasi, krisis, reaksi dan koda.

1) Abstrak, bagian di awal paragraf yang berfungsi memberi gambaran tentang isi teks. Biasanya bagian ini menunjukkan hal unik yang akan ada dalam teks.

2) Orientasi, adalah bagian yang menunjukkan awal kejadian cerita atau latar belakang bagaimana peristiwa terjadi. Biasanya penulis bercerita dengan detail di bagian ini.

3) Krisis, adalah bagian di mana terjadi hal atau masalah yang unik atau tidak biasa yang terjadi pada si penulis atau orang yang diceritakan.

4) Reaksi, adalah bagian bagaimana cara penulis atau orang yang ditulis menyelesaikan masalah yang timbul di bagian krisis tadi.

5) Koda, merupakan bagian akhir dari cerita unik tersebut. Biasanya pun dilakukan dengan memberi kesimpulan tentang kejadian yang dialami penulis atau orang yang ditulis. 
Kemendikbud

(2013:

111)

mengemukakan ciri kebahasaan dalam teks anekdot, sebagai berikut:

1) Disajikan dalam bahasa lucu, bahasa yang digunakan dalam penulisan teks anekdot dapat diplesetkan menjadi bahasa yang lucu.

2) Berisi peristiwa-peristiwa yang membuat jengkel, cerita dalam teks anekdot itu dibuat konyol bagi partisipan yang mengalaminya.

Menurut Berger dalam Sugiarto (2016: 5-7) secara garis besar teknik penciptaan humor itu dapat dikelompokkan dalam beberapa kategori, meliputi: Language (the humor is verbal), Logic (the humor is ideation), Identity (the humor is existential).

Dalman (2015: 15) menyatakan bahwa proses penulisan melibatkan beberapa tahap, yaitu: a. tahap prapenulisan, $b$. tahap penulisan, dan $c$. tahap penyuntingan.

Cinta tanah air adalah mengenal dan mencintai wilayah nasionalnya sehingga selalu waspada serta siap membela tanah air Indonesia terhadap segala bentuk ancaman, tantangan, hambatan, dan gangguan yang dapat membahayakan kelangsungan hidup bangsa dan negara oleh siapapun dan dari manapun (Achmadi, 2009: 87-88).

Cinta tanah air yaitu mencakup sikap dan perilaku yang mencerminkan rasa bangga, setia, peduli, dan penghargaan yang tinggi terhadap bahasa, budaya, ekonomi, politik, dan sebagainya, sehingga tidak mudah menerima tawaran bangsa lain yang dapat merugikan bangsa sendiri (Suyadi, 2013: 9).

\section{METODE PENELITIAN}

Penelitian ini menggunakan metode Research and Development (R\&D). Menurut Sugiyono dalam Rahmawati \& Suseno, 2016: 10 penelitian research and development yaitu penelitian yang digunakan untuk menghasilkan produk tertentu, dan menguji keefektifan produk.

Langkah-langkah penelitian dan pengembangan yaitu: 1) potensi dan masalah, 2) pengumpulan data, 3) desain produk, 4) validasi desain, 5) revisi desain, 6) uji coba produk, 7) revisi produk, 8) uji coba pemakaian, 9) revisi produk, 10) produksi masal (Sugiyono, 2009: 298). Penelitian ini bertujuan untuk mengembangkan buku pengayaan menulis teks anekdot untuk siswa SMA, sehingga dalam prosesnya hanya diutamakan untuk mengembangkan prototipe tanpa diujikan langsung dalam pembelajaran. Agar sesuai dengan maksud dan tujuan penelitian ini, maka penelitian menyederhanakan langkahlangkah penelitian menjadi lima tahap penelitian. Langkah-langkah tersebut dijabarkan sebagai berikut: 1) Potensi dan masalah. Pada tahap awal ini yang dilakukan peneliti adalah merumuskan tujuan produk analisis dan kebutuhan. Kegiatan yang dilakukan meliputi: a) mencari sumber pustaka dan hasil penelitian yang relevan dan b) menganalisis kebutuhan pengembangan buku pengayaan menulis teks anekdot bermuatan cinta tanah air untuk menumbuhkan sikap patriotisme bagi siswa kelas X SMA dan guru. Setelah peneliti mengetahui kebutuhan yang ada di sekolah, peneliti merencanakan awal pengembangan buku pengayaan.

2) Pengumpulan Data. Tahap ini meliputi kegiatan a) penyusunan prinsipprinsip pengembangan buku pengayaan menulis teks anekdot bermuatan cinta tanah air untuk menumbuhkan sikap patriotisme bagi siswa kelas X SMA berdasarkan kajian pustaka dan analisis kebutuhan. b) Persiapan penyusunan pengembangan buku pengayaan menulis teks anekdot bermuatan cinta tanah air untuk menumbuhkan sikap patriotisme bagi siswa kelas X SMA.

3) Desain Produk. Dalam tahap ini yang dilakukan peneliti adalah merancang dan menyusun draf buku pengayaan 
menulis teks anekdot bermuatan cinta tanah air untuk menumbuhkan sikap patriotisme bagi siswa kelas X SMA sesuai hasil analsis kebutuhan siswa dan guru SMA yang telah diperoleh dari subjek penelitian yang telah ditetapkan.

4) Validasi Produk. Tahap ini merupakan proses penilaian atau validasi draf buku pengayaan menulis teks anekdot bermuatan cinta tanah air untuk menumbuhkan sikap patriotisme bagi siswa kelas X SMA oleh dosen ahli untuk mendapatkan saran perbaikan produk.

5) Revisi Desain. Tahap terakhir dalam penelitian dan pengembangan ini adalah proses memperbaiki kesalahan dalam penulisan buku pengayaan setelah dilakukan validasi produk atau draf oleh dosen ahli sesuai saran perbaikan dan konsep yang dimiliki oleh peneliti.

Siswa yang menjadi subjek penelitian dalam rangka memperoleh data tentang kebutuhan buku pengayaan menulis teks anekdot bermuatan cinta tanah air untuk siswa SMA adalah siswa dari tiga sekolah yang memiliki kategori berbeda, yaitu SMA Negeri 1 Ambarawa, SMA Sudirman, dan SMK Baktiawam. Instrumen penelitian meliputi lembar angket kebutuhan untuk siswa dan guru. Angket uji validasi untuk dosen ahli. Data yang terkumpul dianalisis dengan teknik deskriptif kualitatif.

\section{HASIL DAN PEMBAHASAN}

Hasil penelitian yang dipaparkan pada bab ini meliputi empat hal, yaitu 1) hasil analisis kebutuhan siswa dan guru pada buku pengayaan menulis teks anekdot bermuatan cinta tanah air untuk menumbuhkan sikap patriotisme, 2) prinsip pengembangan buku pengayaan menulis teks anekdot bermuatan cinta tanah air untuk menumbuhkan sikap patriotisme, 3) prototipe buku pengayaan menulis teks anekdot bermuatan cinta tanah air untuk menumbuhkan sikap patriotisme dari dosen ahli, dan 4) hasil penilaian dan perbaikan buku pengayaan menulis teks anekdot bermuatan cinta tanah air untuk menumbuhkan sikap patriotisme.

Kebutuhan siswa terhadap buku pengayaan menulis teks anekdot dibagi menjadi tujuh aspek, yaitu: 1) aspek kebutuhan buku pengayaan, 2) aspek materi dan isi buku, 3) aspek muatan cinta tanah air dan sikap patriotisme, 4) aspek penyajian, 5) aspek bahasa dan keterbacaan, 6) aspek grafika, dan 7) aspek harapan terhadap buku pengayaan menulis teks anekdot. Berikut uraian kelima aspek tersebut.

Pada aspek pertama yaitu kebutuhan buku pengayaan peneliti menyertakan tujuh sub aspek, yaitu: 1) kendala pembelajaran menulis teks anekdot, 2) kemudahan dalam menerangkan materi teks anekdot, 3) ketersediaan buku pengayaan tentang teks anekdot, 4) sumber belajar materi menulis teks anekdot, 5) kualitas buku pembelajaran teks anekdot, 6) kesesuaian buku teks dengan $\mathrm{SK} / \mathrm{KD}$, dan 7) pendapat guru terhadap kebutuhan buku pengayaan menulis teks anekdot bermuatan cinta tanah air.

Pada aspek kedua, peneliti menyertakan sembilan sub aspek, yaitu: 1) materi yang disajikan, 2) materi yang diinginkan, 3) penyusunan materi, 4) contoh teks, 5) rangkuman materi, 6) penekanan pada aspek tertentu, 7) judul buku, 8) alur, dan 9) amanat.

Pada aspek ketiga, peneliti menyertakan tiga sub aspek, yaitu: 1) pendapat siswa terhadap buku pengayaan menulis teks anekdot bermuatan cinta tanah air untuk menumbuhkan sikap patriotisme, 2) pendapat siswa terhadap muatan cinta tanah air dan sikap patriotisme pada materi teks anekdot, dan 3) pendapat siswa terhadap muatan cinta tanah air dan sikap patriotisme pada contoh teks anekdot.

Pada aspek keempat, peneliti menyertakan lima sub aspek. Sub aspek yang terdapat dalam aspek ini yaitu: 1) kebutuhan urutan dan hubungan antar 
materi yang disajikan logis dan sistematis, 2) penyajian struktur teks anekdot, 3) kebutuhan buku pengayaan yang menarik perhatian, 4) kebutuhan buku pengayaan yang mudah dipahami, dan 5) penggunaan simbol dan penomoran.

Pada aspek kelima, peneliti menyertakan dua sub aspek. Sub aspek yang terdapat dalam aspek ini yaitu: 1) penggunaan ragam bahasa dalam buku pengayaan menulis teks anekdot, dan 2) pemilihan kosa kata dalam buku pengayaan menulis teks anekdot.

Pada aspek keenam, peneliti menyertakan enam sub aspek, yaitu: 1) cover/ sampul buku (warna dan gambar), 2) ukuran buku, 3) jenis warna kertas, 4) huruf (jenis dan ukuran, 5) ilustrasi atau gambar, dan 6) penomoran halaman.

Pada aspek ketujuh, peneliti menyertakan harapan para siswa terhadap buku pengayaan menulis teks anekdot berupa pertanyaan uraian.

Kebutuhan guru terhadap buku pengayaan menulis teks anekdot bermuatan cinta tanah air untuk menumbuhkan sikap patriotisme pada siswa kelas X SMA dibagi menjadi tujuh aspek, yaitu: 1) aspek kebutuhan buku pengayaan, 2) aspek materi dan isi buku, 3) aspek muatan cinta tanah air dan sikap patriotisme, 4) aspek penyajian, 5) aspek bahasa dan keterbacaan, 6) aspek grafika, dan 7) aspek harapan terhadap buku pengayaan menulis teks anekdot.

Pada aspek pertama yaitu kebutuhan buku pengayaan peneliti menyertakan tujuh sub aspek, yaitu:1) kendala pembelajaran menulis teks anekdot, 2) kemudahan dalam menerangkan materi teks anekdot, 3) ketersediaan buku pengayaan tentang teks anekdot, 4) sumber belajar materi menulis teks anekdot, 5) kualitas buku pembelajaran teks anekdot, 6) kesesuaian buku teks dengan $\mathrm{SK} / \mathrm{KD}$, dan 7) pendapat guru terhadap kebutuhan buku pengayaan menulis teks anekdot bermuatan cinta tanah air untuk menumbuhkan sikap patriotisme.
Pada aspek kedua, peneliti menyertakan sembilan sub aspek, yaitu: 1) materi yang disajikan, 2) materi yang diinginkan, 3) penyusunan materi, 4) contoh teks, 5) rangkuman materi, 6) penekanan pada aspek tertentu, 7) judul buku, 8) alur, dan 9) amanat.

Pada aspek ketiga, peneliti menyertakan tiga sub aspek, yaitu: 1) pendapat guru terhadap buku pengayaan menulis teks anekdot bermuatan cinta tanah air untuk menumbuhkan sikap patriotisme, 2) pendapat guru terhadap muatan cinta tanah air dan sikap patriotisme pada materi teks anekdot, dan 3) pendapat guru terhadap muatan cinta tanah air dan sikap patriotisme pada contoh teks anekdot.

Pada aspek keempat, peneliti menyertakan lima sub aspek, yaitu: 1) kebutuhan urutan dan hubungan antar materi yang disajikan logis dan sistematis, 2) penyajian struktur teks anekdot, 3) kebutuhan buku pengayaan yang menarik perhatian, 4) kebutuhan buku pengayaan yang mudah dipahami, dan 5) penggunaan simbol dan penomoran.

Pada aspek kelima, peneliti menyertakan dua sub aspek, yaitu: 1) penggunaan ragam bahasa dalam buku pengayaan menulis teks anekdot, dan 2) pemilihan kosa kata dalam buku pengayaan menulis teks anekdot.

Pada aspek keenam, peneliti menyertakan enam sub aspek, yaitu: 1) cover/ sampul buku (warna dan gambar), 2) ukuran buku, 3) jenis warna kertas, 4) huruf (jenis dan ukuran), 5) ilustrasi atau gambar, dan 6) penomoran halaman.

Pada aspek ketujuh, peneliti menyertakan harapan guru terhadap buku pengayaan menulis teks anekdot berupa pertanyaan uraian

Berdasarkan analisis kebutuhan siswa dan guru dapat disimpulkan bahwa buku pengayaan menulis teks anekdot bermuatan cinta tanah air untuk menumbuhkan sikap patriotisme yang diharapkan oleh siswa dan guru adalah buku pengayaan menulis teks anekdot 
yang tidak hanya berisi materi, namun dilengkapi dengan gambar-gambar yang berwarna agar tidak membosankan. Selain itu, siswa dan guru juga berharap agar bahasa dalam penyampaian materi mudah dipahami dan dilengkapi dengan contoh teks anekdot bermuatan cinta tanah air.

$\begin{gathered}\text { Prinsip } \\ \text { pengayaan menulis teks anekdot }\end{gathered}$
menbangan bermuatan cinta tanah air ditetapkan menjadi 5 aspek pengembangan buku, antara lain: 1) aspek materi, 2) aspek penyajian materi, 3) aspek bahasa, 4) aspek grafika dan 5) aspek muatan cinta tanah air.

Aspek materi dalam pengembangan buku pengayaan menulis teks anekdot bermuatan cinta tanah air, dapat dijabarkan dalam sebelas sub aspek, antara lain: 1) kelengkapan materi, 2) uraian materi, 3) teori yang digunakan, 4) penyusunan materi bermuatan, 5) penyajian contoh teks, 6) jumlah contoh teks, 7) penyajian rangkuman, 8) penekanan pada aspek tertentu, 9) judul buku pengayaan, 10) kesulitan dalam pemahaman alur, 11) penyajian amanat.

Aspek penyajian materi dalam buku pengayaan diwujudkan melalui beberapa sub aspek, antara lain: 1) urutan penyajian materi, 2) penyajian struktur teks anekdot, 3) kebutuhan desain buku pengayaan, 4) pola penyajian materi, dan 5) penggunaan simbol dan penomoran.

Aspek bahasa dan keterbacaan dalam pengembangan buku pengayaan menulis teks anekdot bermuatan cinta tanah air diwujudkan melalui dua indikator, yaitu 1) penggunaan ragam bahasa dalam buku, 2) pilihan kata dalam buku dan struktur kalimat.

Segi aspek grafika pengembangan buku pengayaan menulis teks anekdot bermuatan cinta tanah air diwujudkan berdasarkan beberapa sub aspek sebagai berikut. 1) cover (warna sampul), 2) ukuran buku, 3) warna kertas, 4) jenis huruf, 5) ukuran huruf, 6) ilustrasi gambar, 7) penomoran halaman.
Aspek muatan cinta tanah air terdiri atas empat indikator, antara lain: 1) kehadiran muatan cinta tanah air, 2) muatan nilai karakter yang harus ada dalam buku pengayaan, 3) pengintegrasian cinta tanah air dan paatriotisme pada materi teks anekdot, 4) pengintegrasian cinta tanah air dan sikap patriotisme pada contoh teks anekdot.

Prototipe buku pengayaan menulis teks anekdot bermuatan cinta tanah air terdiri atas kulit buku dan bagian-bagian buku. Adapun unsur kulit buku terdiri atas kulit depan, kulit belakang, dan punggung buku. Selanjutnya, bagian-bagian buku terdiri atas bagian awal, bagian isi, dan bagian akhir.

Kulit buku terdiri dari tiga bagian, antara lain: 1) Kulit depan buku berisi judul buku dan nama penulis. 2) Kulit belakang berisi deskripsi singkat isi buku 3) Bagian punggung buku merupakan salah satu desain buku yang berisi judul buku pengayaan menulis teks anekdot.

Pada bagian awal terdiri atas empat komponen, yaitu 1) halaman judul, 2) halaman penerbitan, 3) halaman prakata, dan 4) daftar isi. Bagian isi buku pengayaan menulis teks anekdot bermuatan cinta tanah air, terdiri dari 4 bab, yaitu 1) Mengenal Cinta Tanah Air melalui Teks Anekdot, 2) Cinta Tanah Air dan Patriotisme, 3) Teknik Penciptaan Humor dan Langkah-langkah Menulis Teks Anekdot, 4) Contoh-contoh Teks Anekdot Bermuatan Cinta Tanah Air. Pada bagian akhir berisikan mengenai profil penulis, glosarium dan daftar pustaka.

Penilaian dan perbaikan prototipe buku pengayaan menulis teks anekdot bermuatan cinta tanah air untuk menumbuhkan sikap patriotisme.

Penilaian pada aspek kelayakan materi buku pengayaan menulis teks anekdot bermuatan cinta tanah air, nilai rata-rata yang diperoleh dari penilaian dosen ahli 75, 575 dengan kategori baik. Pada aspek penyajian materi buku pengayaan menulis teks anekdot bermuatan cinta tanah air, nilai dari dosen ahli 78,125 dengan 
kategori baik. Pada aspek bahasa dan keterbacaan buku pengayaan menulis teks anekdot bermuatan cinta tanah air, nilai dari dosen ahli 79,16 dengan kategori baik. Pada aspek kelayakan grafika buku pengayaan menulis teks anekdot bermuatan cinta tanah air, nilai dari dosen ahli 75 dengan kategori baik. Pada aspek kelayakan muatan cinta tanah air buku pengayaan menulis teks anekdot bermuatan cinta tanah air, nilai dari dosen ahli 81,25 dengan kategori baik.

Perbaikan pada buku pengayaan menulis teks anekdot bermuatan cinta tanah air untuk menumbuhkan sikap patriotisme yaitu: 1) mengubah desain kulit buku atau kover depan dan balakang menjadi lebih menarik, 2) menekankan materi menulis sehingga dalam desain produk akhir menjadi tujuh bab yaitu bab I mengenai mengenal teks anekdot, bab II mengenai teknik penciptaan humor, bab III prapenulisan teks anekdot, bab IV mengenai penulisan teks anekdot, bab $\mathrm{V}$ mengenai penyuntingan teks anekdot, bab VI mengenai cinta tanah air dan patriotisme, dan bab VII mengenai menulis teks anekdot bermuatan cinta tanah air, 3) menganti huruf menjadi font casandra, serta 4) menambahkaan indeks.

Buku pengayaan menulis teks anekdot bermuatan cinta tanah air untuk menumbuhkan sikap patriotisme yang dikembangkan oleh peneliti memiliki beberapa keunggulan, yaitu: 1) berisikan mengenai mengenal teks anekdot, teknik penciptaan humor, langkah-langkah menulis teks anekdot, langkah-langkah menulis teks anekdot bermuatan cinta tanah air dan contoh teks anekdot bermuatan cinta tanah air. Hal tersebut merupakan pengetahuan dan pemahaman dasar yang dapat dijadikan acuan para siswa dalam menyajikan teks anekdot. 2) Buku pengayaan menulis teks anekdot bermuatan cinta tanah air berisikan langkah-langkah menulis teks anekdot dan teknik penciptaan humor. Dalam bab ini dilengkapi dengan contoh teks anekdot, langkah-langkah dalam pembuatan teks anekdot telah diuraikan dalam buku pengayaan melalui tiga bab sebagai berikut. 1) prapenulisan, 2) penulisan, 3) penyuntingan. Hal tersebut bertujuan agar siswa lebih mudah memahami dan mempraktikkan membuat teks anekdot sesuai dengan langkah-langkah dengan penciptaan humornya. 3) Buku pengayaan menulis teks anekdot bermuatan cinta tanah air menyajikan materi cinta tanah air sebagai pelengkap muatan yang dihadirkan materi tersebut merupakan pengetahuan dasar siswa tentang arti cinta tanah air. 4) Buku pengayaan menulis teks anekot bermuatan cinta tanah air menyajikan beragam contoh teks anekdot yang disertai muatan cinta tanah air. Hal ini sangat penting diketahui para siswa yaitu nilainilai yang terkandung dalam sikap cinta tanah air sehingga dapat menumbuhkan sikap patriotisme di kehidupan sehari-hari bagi diri sendiri, sekolah, dan masyarakat.

\section{SIMPULAN}

Sebagai produk pengembangan buku pengayaan untuk siswa SMA, buku ini dapat diproduksi dan dipasarkan dalam skala besar. Produk buku pengayaan menulis teks anekdot bermuatan cinta tanah air untuk menumbuhkan sikap patriotisme memenuhi kebutuhan sebagai penunjang pembelajaran bagi siswa SMA. Penyusunan buku pengayaan menulis teks anekdot bermuatan cinta tanah air untuk menumbuhkan sikap patriotisme ini sudah dilengkapi dengan contoh sesuai dengan kebutuhan siswa SMA. Oleh karena itu, buku pengayaan menulis teks anekdot bermuatan cinta tanah air untuk menumbuhkan sikap patriotisme dapat dijadikan sebagai buku pendamping dalam pembelajaran menulis teks anekdot.

Buku pengayaan menulis teks anekdot bermuatan cinta tanah air untuk menumbuhkan sikap patriotisme ini hendaknya memberikan perhatian lebih pada ketersediaan buku-buku pengayaan menulis teks anekdot yang dapat memberikan keterampilan praktis bagi 
siswa, agar siswa dapat belajar menulis teks anekdot dengan baik dan benar. Buku pengayaan menulis teks anekdot bermuatan cinta tanah air untuk menumbuhkan sikap patriotisme ini perlu dilakukan penelitian lebih lanjut untuk menguji keefektifan buku pengayaan menulis teks anekdot bermuatan cinta tanah air untuk menumbuhkan sikap patriotisme yang sudah ada terhadap pembelajaran menulis teks anekdot di sekolah.

\section{DAFTAR PUSTAKA}

Achmadi, A. 2009. Filsafat Pancasila dan Kewarganegaraan. Semarang: RaSAIL Media Group.

Dalman. 2015. Keterampilan Menulis.Jakarta: PT Rajagrafindo Persada.

Hartono, B. 2016. Dasar-dasar Kajian Buku Teks. Semarang: Unnes Press.

Nurjamal, D., \& Sumirat, W. 2010. Penuntun Perkuliahan Bahasa Indonesia. Bandung: Alfabeta.

Pertiwi, D. O., Hartono, B., \& Syaifudin, A. 2016. Pengembangan Buku Pengayaan Menyusun Teks Eksposisi Berbasis Kearifan Lokal Bagi Siswa Sekolah Menengah Pertama (SMP). Jurnal Pendidikan Bahasa dan Sastra Indonesia, 5(2), 62-69.

Keraf, Gorys. 2007. Argumentasi dan Narasi. Jakarta: Gramedia Pustaka Utama.

Kemendikbud. 2013. Kurikulum 2013, Standar Kompetensi Dasar Sekolah Menengah Atas (SMA)/Madrasah Aliyah (MA). Jakarta.

Kompasiana. 2017. Manfaat atau Pentingnya Buku untuk Hari Ini dan Masa Depan.https://www.kompasiana.com/han.okumura/manfaat-ataupentingnya-bukuuntuk-hari-ini-dan-masa-depan_591bc4ac917e61b71392735a. Diakses pada tanggal 9 Januari 2019.

Pusat Perbukuan Departemen Pendidikan Nasional. 2008. Pedoman Penulisan Buku Nonteks. Jakarta: Pusat Perbukuan Departemen Pendidikan Nasional.

Rahmawati, L. S., \& Suseno, S. 2016. Pengembangan Buku Panduan Bermain Peran Untuk Siswa SMP. Jurnal Pendidikan Bahasa dan Sastra Indonesia, 5(2), 8-12.

Rahmayanti, D., Martha, I. N., \& Wisudariani, N. M. R. 2015. Pembelajaran Menulis Teks Anekdot Pada Mata Pelajaran Bahasa Indonesia Dalam Kurikulum 2013 Di Kelas XA Akuntansi Smk Negeri 1 Singaraja. Jurnal Pendidikan Bahasa Dan Sastra Indonesia Undiksha, 3(1).

Rianto, H., \& Firmansyah, S. 2017. Upaya Mewujudkan Pemahaman Nilai-Nilai Patriotisme Dalam Bersikap Mahasiswa Program Studi Ppkn Ikip Pgri Pontianak. Sosial Horizon: Jurnal Pendidikan Sosial, 4(1), 86-96.

Rosidi, I. 2009. Menulis siapa takut. Kanisius.

Setiawan, Arwah. 1990. Teori Humor. Jakarta: Majalah Astaga, 3(3), 34-35.

Sitepu, B.P. 2012. Penulisan Buku Teks Pelajaran. Bandung: PT Remaja Rosdakarya Offset.

Sugiarto, Vania, D. 2016. Teknik Humor dalam Film Komedi yang Dibintangi oleh Stand Up Comedyan. Jurnal E-Komunikasi.

Sugiyono. 2009. Metode Penelitian Pendidikan Pendekatan Kuantitatif, Kualitatif, dan $R \& D$. Bandung : Alfabeta.

Suryaman, Maman. 2010. Penggunaan Bahasa di Dalam Penulisan Buku Nonteks Pelajaran. Yogyakarta: Pusat Perbukuan Departemen Pendidikan Nasional.

Suyadi. 2013. Strategi Pembelajaran Pendidikan Karakter. Bandung: PT Remaja Rosdakarya Offset.

Tarigan, H. G. 1986. Menyimak sebagai suatu keterampilan berbahasa. Penerbit Angkasa Bandung. 
Wahyudi, J. 2010. Meningkatkan Profesionalisme Guru dengan Menulis Buku. https://www.kompasiana.com/johanmenulisbuku/54ffb675a33311894c510fa1/menin gkatkan-profesionalisme-guru-dengan-menulis-buku. Diakses pada tanggal 9 Januari 2019.

Widayani, N. E. 2016. Penanaman Nilai Cinta Tanah Air di SD Negeri Sedayu 1 Muntilan Magelang Tahun Ajaran 2014-2015. BASIC EDUCATION, 5(4), 313-323.

Wiyanto, A. 2006. Terampil Menulis Paragraf. Jakarta: Gramedia.

Zulaeha, I. 2016. Teori, Model, dan Implementasi Pembelajaran Menulis Kreatif. Semarang: Unnes Press.

Zulaeha, I. 2017. Keefektifan Pembelajaran Menulis Teks Eksposisi Bermuatan Konservasi dengan Model CIRC dan TTW Berdasarkan Gaya Belajar pada Peserta Didik Kelas X. Laporan Penelitian. Semarang: Fakultas Bahasa dan Seni Universitas Negeri Semarang. 